\title{
Article
}

http://dx.doi.org/10.11646/phytotaxa.175.1.2

\section{A taxonomic study of Sedum series Rupestria (Crassulaceae) naturalized in North America}

\author{
LORENZO GALLO ${ }^{1} \&$ PETER F. ZIKA ${ }^{2}$ \\ ${ }^{I}$ Strada Val San Martino sup. 194.10131,Torino, Italy.E-mail: lorenzogallo1959@hotmail.it \\ ${ }^{2}$ WTU Herbarium, Box 355325, University of Washington, Seattle, WA 98195-5325, USA. \\ E-mail:Zikap@comcast.net
}

\begin{abstract}
Sedum rupestre L. and its close relatives (Sedum series Rupestria) are native to Europe. Adventive populations in North America were studied both in the field and the herbaria. Our results exclude $S$. rupestre L. and include recognition of two additional taxa on the continent, which are distinguished with keys and illustrations: Sedum forsterianum documented as a naturalized species in the United States, from Washington, and in British Columbia, Canada and Sedum thartii, naturalized in Colorado, Maine, Ohio, Oregon, Washington and Ontario, Canada. A lectotype is established for S. forsterianum.
\end{abstract}

Key words: Alien, stonecrop, typification

\section{Introduction}

The genus Sedum Linnaeus (1753: 430) is widespread in Europe, Africa, Asia and America and includes roughly 400 to 475 taxa according to the most recent authors (Eggli et al. 1995, 't Hart \& Bleij 2003, Thiede \& Eggli 2007, Ohba 2009).

Berger (1930) devised an infrafamilial classification of the Crassulaceae. Within the genus Sedum he recognised "Sektion 17" (Sedum proper, his "Seda genuina") and, inside it, several "Reihen" or series. The "Reihe" 20 group of Sedum is now known as Sedum series Rupestria (Berger 1930: 456), a monophyletic and well delimited group endemic to the Euro-Mediterranean region, including 17 among species, subspecies and natural hybrids (Hart ' $t$ 1994, Hart 't \& Bleij 2003, Gallo 2009, 2012). Sedum series Rupestria is well known in North American gardens, where it escapes locally and has established wild populations in nine states and provinces (Ohba 2009). These reports are discussed below. Members of the series are unknown in Mexico (Meyrán Garcia \& López Chávez 2003) whereas $S$. reflexum L. (1755: 463) was reported as naturalized in New Zealand (Healy, 1959; Given, 1984) and S. thartii L.P. Hebért (1983: 211) in Argentina (Oggero et al. 2013, Arana et al., in press).

North American reports of Sedum series Rupestria all refer to S. rupestre L. (1753: 431; syn. S. reflexum). Ohba (2009) reported it was introduced in Quebec, Georgia, Illinois, Indiana, Maine, Massachusetts, New Jersey, New York, and Ohio, on rock ledges at elevations below $2000 \mathrm{~m}$ (likely a typographical error for $200 \mathrm{~m}$ ). Ohba (2009) also mentioned ephemeral escapes or waifs from Prince Edward Island and Ontario. Previously, Britton \& Rose (1905), Britton \& Brown (1947) and Mitchell \& Tucker (1997) noted S. rupestre (as S. reflexum) escaped from gardens in Massachusetts and New York. Clausen (1975: 554 and 579) cited S. rupestre (as S. reflexum) among the taxa naturalized in eastern North America, dating back to 1876, while the first cultivated record goes back to 1816 (Gray 1876); Clausen (1975: 577) also discussed $S$. rupestre, but only as a cultivated species. We treat $S$. reflexum as a synonym of $S$. rupestre, following 't Hart \& Jarvis (1993). Finally, Haines \& Vining (1998) and Haines (2011) cite $S$. ochroleucum Chaix (1786: 325) as a local garden escape.

Members of Sedum series Rupestria are distinguished by subtle characters that often are not preserved well in the herbaria. In addition, the taxonomic conclusions in recent European literature on the complex have not been widely applied to naturalized populations in North America (e.g., Gallo 2009, 2012, 2013, 2014). 


\section{References}

Arana, M., Gallo, L., Oggero, A.J. \& Sieburger, I. (In press) Remarks on Sedum thartii (Crassulaceae) an exotic species naturalized in Argentina. Webbia.

Berger, A. (1930) Crassulaceae. In: Engler, A. \& Prantl, K. (Eds.) Die natürlichen pflanzenfamilien. W. Engelmann, Leipzig, pp. 449459.

Britton, N. \& Brown, A. (1947) An Illustrated Flora of the Northern United States, Canada and the British possessions. Vol. II. Amaranthaceae to Loganiaceae. The New York Botanical Garden, New York. Pp. 207-210.

Britton, N. \& Rose, J.N. (1905) [reprint 1961] Crassulaceae. In: Small, J.K. (Ed.) North American Flora. Rosales, vol. 22, part 1. The New York Botanical Garden, New York, pp. 66.

Candolle, A.P. de (1808) Rapport sur un voyage botanique et agronomique dans les Départemens du Sud-Ouest. Mémoires de la Société d'agriculture du départment de la Seine 11: 1-72.

Chaix, D. (1786) Plantae vapincenses sive enumeratio in agro Vapincensi observatarum stirpium. In: Villars, D. (Ed.) Histoire des plantes de Dauphiné 1. - Grenoble: chez l'Auteur \& chez les Libraires; Lyon: chez les Frères Perisse, \& chez Piestre \& de la Moliere; Paris: chez Prevost, Quai des Augustins, \& c., pp. 309-382.

Chamberlain, E.B. (1912) A Sedum new to North America. Rhodora 14: 227-228.

Clausen, R.T. (1975) Sedum of North America north of the Mexican Plateau. Comstock Book. Cornell University Press. Ithaca, 742 pp.

Consortium of Pacific Northwestern Herbaria. Herbarium specimen from the Pacific Northwest (2014). Available from: http://www. pnwherbaria.org/index.php (accessed: 28 March 2014).

Eggli, U., Hart, 't H. \& Nyffeler, R. (1995) Toward a consensus classification of the Crassulaceae. In: Hart, 't H. \& Eggli, U. (Eds.) Evolution and Systematics of the Crassulaceae. Backhuys Publ. Leiden, pp. 173-192.

Euro+Med (2006+, continuously updated). Euro+Med PlantBase. The information resource for Euro-Mediterranean plant diversity. Available from: http://ww2.bgbm.org/EuroPlusMed/ (accessed: 13 November 2013).

Evans, R.L. (1983) Handb. cult. Sedums. Science Reviews Lim. 345 pp.

Fiori, A. (1924) Nuova Flora Analitica d'Italia. Vol. I. Edagricole, Bologna. 944 pp.

Gallo, L. (2000) Contributi allo studio dei Sedum della serie Rupestria Berger (Crassulaceae) dell'Italia nord-occidentale. I. Prime segnalazioni di S. montanum Song. \& Perr. subsp. orientale ‘t Hart per il Piemonte. Archivio Geobotanico Pavia 6 (1): $79-82$.

Gallo, L. (2009) Sedum ser. Rupestria Berger (Crassulaceae): work in progress toward a checklist of taxa and their distribution. Bocconea 23: 203-205.

Gallo, L. (2012) Natural hybrids in Sedum series Rupestria Berger (Crassulaceae): a review of taxonomy and nomenclature. Forum Geobotanicum 6: 1-13.

Gallo, L. (2013) Neotypification of Sedum ochroleucum Chaix (Crassulaceae). Atti della Società Italiana di Scienze Naturali e del Museo Civico di Storia Naturale in Milano 154:57-64.

Gallo, L. (2014) Sedum ochroleucum subsp. mediterraneum (Crassulaceae), a new Italian endemic taxon. Willdenowia 44 (1): $27-33$.

Gallo, L. \& Bracchi, G. (2005) Aggiornamento alla conoscenza delle Crassulaceae dell'Emilia-Romagna, con segnalazioni per la Liguria orientale e la Toscana settentrionale. Atti Società italiana Scienze Naturali Museo civico Storia Naturale Milano 146 (2): $135-148$.

Given, D.R. (1984) Checklist of dicotyledons naturalized in New Zealand 17. Crassulaceae, Escalloniaceae, Philadelphaceae, Grossulariaceae, Limnanthaceae. New Zealand Journal of Botany 22: 191-193.

http://dx.doi.org/10.1080/0028825x.1984.10425250

Gleason, H.A. (1952) The new Britton and Brown illustrated flora of the northeastern United States and adjacent Canada. Vol. 2. The choripetalous Dicotyledoneae. The New York Botanical Garden and Hafner Press, New York. 655 pp.

Gleason, H.A. \& Cronquist, A. (1991) Manual of vascular plants of northeastern United States and adjacent Canada, 2nd ed. The New York Botanical Garden, Bronx. 910 pp.

Gray, A. (1876) Sedum reflexum L. American Naturalist 10: 553.

Grulich, V. (1984) Generic dividion [sic] of Sedoideae in Europe and its adjacent region. Preslia 56: $29-46$.

Haines, A. (2011) New England Wildflower Society's Flora Novae Angliae; A manual for the identification of native and naturalized higher vascular plants of New England. New England Wildflower Society and Yale University Press, New Haven. 973 pp.

Haines, A. \& Vining, T.F. (1998) Flora of Maine, a manual for identification of native and naturalized vascular plants of Maine. V. F. Thomas Co., Bar Harbor. 837 pp.

Hart, H. 't (1978) Biosystematic studies in the Acre-group the series Rupestria Berger of the genus Sedum L. (Crassulaceae). Drukkerij Elinkwijk BV, Utrecht, 153 pp.

Hart, H. 't (1994) The Sedum rupestre group. Sedum Society Newsletter 28: 8-22. 
Hart, H. 't \& Bleij, B. (2003) Sedum. In: Eggli, U. (Ed.) Illustrated Handbook of Succulent Plants. Crassulaceae. Springer, Berlin, pp. $235-332$.

Hart, H. 't \& Jarvis, C. (1993) Typification of Linnaeus's names for European species of Sedum subgen. Sedum (Crassulaceae). Taxon, 42: $399-410$.

http://dx.doi.org/10.2307/1223149

Healy, A.J. (1959) Contributions to a knowledge of the adventive flora of New Zealand. No. VIII. The "succulent" element of the adventive flora. Transactions of the Royal Society of New Zealand 87: 229-234.

Hebért, L.P. (1983) Analyse d'un complexe chromosomique en Méditerranée: Sedum ser. Rupestria Berger emend. Revue de Cytologie et de Biologie Végétales, le Botaniste 6 (3-4): 179-224.

Hodgdon, A.R. (1959) Sedum sexangulare in New Hampshire. Rhodora 61: 247.

Jalas, J., Suominen, J., Lampinen, R. \& Kurtto, A. (1999) Crassulaceae. In: Schmoe, F.G., Whitzit, D.F. \& Fernatic, E.R. (Eds) Atlas Florae Europaeae. Distribution of vascular plants in Europe, vol. 12, Resedaceae to Platanaceae. The Committee for Mapping the Flora of Europe \& Societas Biologica Fennica Vanamo, Helsinki, pp. 40-127.

Linnaeus, C. (1753) Species Plantarum. Tomus I. Imp. Laurentii Salvii, Holmiae. 560 pp.

Linnaeus, C. (1755) Flora Suecica, editio secunda eucta et emendata. Sumtu \& literis Laurentii Salvii, Stockholm. 464 pp.

Meyrán Garcia, J. \& López Chávez, L. (2003) Las Crasuláceas de México. Sociedad Mexicana de Cactologia A.C. Azcapotzalco, México D.F., 234 pp.

Mitchell, R.S. \& Tucker, G.C. (1997) Revised checklist of New York State plants. New York State Museum Bulletin 490, Albany. 400 pp.

New England Wild Flower Society (2014) Go Botany. Discover thousands of New England plants. Available from: https:/gobotany. newenglandwild.org/species/sedum/ochroleucum/ (accessed: 21 February 2014).

Newton, L.E. (1999) Sedum forsterianum at its type locality. British Cactus and Succulent Society 17 (3): 146.

Nyman, C.F. (1879) Consp. fl. eur., part 2. Typ. Off. Bohlinianae, Orebro.

Oggero, A.J., Arana, M.D., Gallo, L. \& Sieburger, I. (2013) Sedum thartii (Crassulaceae) una nueva especie adventicia para la flora Argentina. Boletín de la Sociedad Argentina de Botánica, 48 (Supl.): 72-73.

Ohba, H. (2009) Sedum. In: Flora of North America Editorial Committee (Eds.) Flora of North America. North of Mexico, vol. 8. Magnoliophyta: Paeoniaceae to EricaceaeOxford Univ. Press, New York, pp. 199-222. Available from: http://www.efloras.org/ florataxon.aspx?flora_id=1\&taxon_id=129989 (accessed online: 2 March 2014).

Praeger, R.L. (1921) An account of the genus Sedum as found in cultivation. Journal of the Royal Horticultural Society, 46, 1-314 pp. http://dx.doi.org/10.5962/bhl.title.15616

Smith, J.E. (1808) English botany; or, coloured figures of British plants, with their essential characters, synonyms, and places of growth: to which will be added, occasional remarks. Vol. 26. James Edward Sowerby, London. Plates 1801-1872.

Songeon, A. \& Perrier, E. (1866) Sur des plantes nouvelles ou peu connues de la Savoie. N. 2. Billotia, 1: 77.

Thiede, J. \& Eggli, U. (2007) Crassulaceae. In: Kubitzki, K. (Ed.) The Families and genera of Vascular Plants, vol. 9. Springer-Verlag, Berlin Heidelberg, pp. 83-118.

http://dx.doi.org/10.1007/978-3-540-32219-1_12

\section{Appendix. Selected herbarium vouchers}

\section{Sedum forsterianum Sm. in Sowerby}

CANADA. British Columbia: Fraser Valley, West Vancouver, Caulfeild Park, southeast facing rocky area at ocean side, 2001 Jun 15, Kennedy \& Ganders 5435 (UBC, V217117). Vancouver Island, Woodhus Slough, between Oyster River and Salmon Point, 200 m east of Salmon Point Pub, 2008 Jun 12, Brears (UBC, V227083). Quadra Island, Quathiaski Cove, north of old ferry road landing, 2003 jun 04, Lomer 4832 (UBC, V231403). Vancouver Island, 10 Km due southeast of Campbell River, Salmon Point, ca. 350 m due southeast of marina, 2010 Jul 11, Lomer 7372 (UBC, V234760). Haida Gwail (Queen Charlotte Island) Graham Island, Skidegate, breakwater along Skidegate Inlet, Highway 33 below 5th Street, 2004 Aug 26, Cheney (UBC, V227088). Vancouver Island, Duncan, island highway

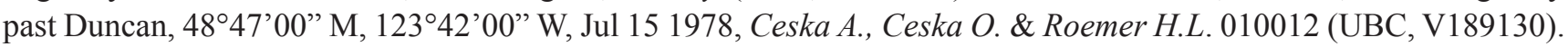
UNITED STATES. Washington: King Co., dry weedy roadside, 1.2 air km WNW of Tradition Lake, Issaquah, 55 m, 6 Jun 2014, Zika 26602 (WTU). Mason Co., S shore of Hood Canal, Route 106 about 3 miles E of Union, common naturalized weed, dry roadsides and steep loose gravel slopes, 3 m, 4 Jul 2010, Zika 25108 (CWG, DAO, MO, NY, UBC, UC, WS, WTU). 